\title{
Empirical Analysis of Macroeconomic Indicators as Determinants of Foreign Direct Investment in Pakistan
}

\author{
${ }^{1}$ Saifullah Malik, ${ }^{2}$ Qaisar Ali Malik \\ ${ }^{I}$ FUIRC, Department of Business \& Economics. \\ ${ }^{2}$ Assistant Professor, FUIRC, Department of Business \& Economics.
}

\begin{abstract}
The aim of the study is to analyze and evaluate the impact of core macroeconomic variables - GDP, Inflation and Exchange Rate on Foreign Direct Investment (FDI) inflows in Pakistan. The role and effect of these macroeconomic variables on the growth of FDI inflows has always been the major area of interest for the economics and finance experts and policy makers of the present era. The study therefore attempts to explore how the core macroeconomic indicators affect the FDI inflows in Pakistan. For this purpose time series data covering four decades from year 1971 to year 2009 has been taken for analysis. The data is taken from online material available at websites of World Development Indicators, International Monetary Fund, State Bank of Pakistan and Economic Survey of Pakistan. Descriptive and inferential statistical analyses are performed to evaluate the data and generalize the results. Pearson Correlation, Augmented Dickey Fuller Unit Root Test, Phillip Peron Unit Root Test, Johnson Co integration Test and Ordinary Least Square technique is used to analyze and conclude the results. The results showed that all three macroeconomic variables are positively associated to the dependent variable - FDI. Data stationarity is confirmed through Phillip Peron test at first difference. Data co integration is checked through Log likelihood Ratio that satisfied co integrating equation at $5 \%$ significance level. The assumption used in this co integration test is intercept with no trend and vector auto regressive with linear deterministic trend. OLS technique is used to measure the strength and significance of explanatory variables against dependent variable. The results show that GDP, inflation and exchange rate have positive impact on FDI inflows, and the model is found to be significant at 1\% level, hence it is concluded that any increase in the three explanatory variables would cause an increase in FDI, therefore government should focus on stabilizing these variables to attract more FDI in to the country to support the economic growth of the country.
\end{abstract}

Keywords: FDI, Inflation, GDP, Exchange Rate

\section{Introduction}

It has been a well established fact that the growth of foreign direct investment (FDI) escalates the economic growth of a country. Primarily the FDI comes into an economy through a foreign country or a company launching a new project or acquiring the already existing domestic projects with huge profit potentials (Sajid et al. 2012). Major focus of foreign countries and foreign companies, while deciding the potential area of investment, has been on FDIs in the host country's industrial sector or its infrastructure. Moreover FDIs are also made to get voting powers in the projects where foreign companies' stakes are involved (Mahmood \& Ehsanullah, 2011). FDI supports the economic growth through bringing in new technologies, creating employment opportunities and enhancing productivity of the economy. Moreover it explores hidden potential markets with high profitability prospects. It also leads to the enhanced and effective management and organizational skills through interaction of two cross border expertise. FDI especially helps under developed and developing countries in enhancing and stabilizing their economic growth (Aurangzeb \& Haq, 2012). FDI is generally attracted by the countries ensuring better prospects of profitability and security of investment. In order to attract FDI the underdeveloped and developing countries have been offering lucrative business prospects to the developed world for investment in their economy. To get the fruitful outcomes of FDI, Pakistan has been following liberal FDI policy for the past two decades. The purpose of such liberal policy has been attracting more investment for the maximization of human capital formation, integrating international trade, creating more competitive business environment and promoting enterprise development.

Presently Pakistan is facing atrocious challenges in form of higher unemployment level, breakdown of law and order situation, massive corruption, bad governance and inadequate infrastructure. The devastating earthquake in year 2005 and unprecedented floods in year 2010 has worsened the situation. Despite these shocks, the survival of the economy has established the potential and strength of Pakistani economy. Hence the foreign investors have been still showing their interest in investing in Pakistani markets. It is strongly believed that Pakistan may improve its economy through FDI, by putting dedicated efforts to improve overall investment environment (Yousaf \& Nasir, 2011). In Pakistan more than $80 \%$ of the FDI has been made in industrial, financial, power and manufacturing sectors. Some of the investment has also been made in textile machines, 
petrochemicals, automobiles and construction/development of infrastructure sectors. These investments have been primarily made by Gulf States, United States of America, Great Britain, China and Netherland (Economic Performance 2010-2012).

Similarly the potential of an economy to attract and retain FDI has its own implications. Such potential is usually measured through various macro-economic indicators like interest rate, gross domestic product (GDP), inflation rate, exchange rate etc. The literature suggests that these variables have been influencing the FDI. Most of the research studies have identified a significant impact of GDP, inflation, exchange rate, export and import quantum and financial policies on FDI in a country. Pakistan has been witnessing a declining trend in FDI. Historically FDI inflows were $\$ 300$ million in 1990-91, it increased to all time highest level of $\$ 5.4$ billion in 2007-08, then it reduced to $\$ 2.4$ billion in 2009-10 and finally it came down to just $\$ 741$ million in 2011-12 (Mahmood \& Ehsanullah, 2011).

\section{Objective of the Study}

Present study intends to empirically evaluate the explanatory role of macroeconomic variables for affecting FDI inflows in Pakistan, to identify how macroeconomic imbalances affect the FDI inflows in the country and what corrective measures could be taken to improve FDI inflows in the country for overall economic growth.

\section{Problem Statement}

Pakistan has been facing declining FDI inflows in the past few years due to various economic, political, legal and social factors. Macroeconomic imbalances have been considered adversely affecting the FDI inflows in the country. The present study is an endeavor to identify and explore how these macroeconomic imbalances measured through various macroeconomic variables affect the FDI inflows in Pakistan.

\section{Literature Review}

It is an old adage that money goes where money is. Hence FDI does not consider any boundaries. Studies show that FDI flows to the region/country which has political stability, good fiscal policies, higher rate of return, attractive market, low cost skilled labour, minimum security risk, quality infrastructure and ease of doing business (Hussain, 2012). Levis (1979) concluded that economic indicators have more powerful effect on FDI than political indicators while Yousaf et al. (2011) stated that FDI helps in transfer of technology, training of untrained skilled labour force and promotion of better management skills from the developed country to the under developed/developing country. Anwara et al. (2010) and Asheghian (2004) found that GDP growth rate has a significant influence on FDI inflows, whereas Arshad (2007) found significant influence of FDI on the economic growth. Santiago (1987) suggested that FDI inflow is affected by macro economic performance of the country. Shah \& Ahmed $(2003 ; 2004)$ and Gul et al. (2012) observed that GDP and FDI are positively associated, whereas they found week positive linkage between FDI and Inflation. Niazi et al. (2011) also found positive association between GDP growth and FDI, and negative relationship between inflation and FDI. Azam \& Naeem (2006; 2009) and Aqeel \& Nishat (2004) found that market size; measured by GDP, domestic investment, trade openness, and return on investment are significantly and positivelu linked with FDI.

Kok \& Ersoy (2009) analyzed 24 developing countries including Pakistan and concluded that market size attracts the FDI. Khan \& Khan (2011) observed that FDI had a predominant role in the economic development of Pakistan. The study suggested that having liberalized policy to attract FDI may have positive impact on economic growth but it may also harm the local industry and thus adversely impact the economic growth of Pakistan. Zaman et al. (2012) discussed that well trained human capital is an asset to usefully harness the impact of FDI. Unfortunately Pakistan has low literacy rate and they have untrained labour force and thus the desired economic growth cannot be achieved. The world economy is passing through a crunch situation, so as the Pakistani economy is suffering. This situation has adversely disturbed the FDI inflows, development aids, foreign remittances, payment schedule of loans, increases in oil imports and decreases in exports. Moreover the budgetary deficits, crash of the stock market, energy shortages and rising inflation of daily usage items have also added to the situation (Aziz, 2009). So the negative impact of economic situation on FDI may not be ruled out (Aseidu, 2005). Sahoor (2006) stated that sharp rise in private capital in developed countries is a major contributory factor for investment in developing countries.

Despite the fact that the world has been seen sharp increase in interest rate, unsteady oil market and imbalance in default payment of loans. The urge to invest has steadily increased. This has happened on account of availability of funds in the developed countries and its best utilization to beneficially investing developing countries. Irfan et al. (2011) stated that GDP, exports, imports and FDI are all interrelated. Sultana et al. (2010) concluded that GDP has a significant impact on national savings and private investment in Pakistan, and inflation rate and high interest rates on advances by banks have also adversely affected the target of higher economic growth. Awan et al. (2010) concluded that inflation rate is significantly affecting investments encouraging the investors with the aim to earn higher profit. Mahmood et al. (2011) observed that frequent 
fluctuation in exchange rate has a negative effect on FDI, hence if a country exchange rate is not stable, foreign investor will not be interested to invest in the country.

Falki (2009) stated that financial policies, political instability, macroeconomic state and poor human capital in Pakistan have been major causes of slow growth of the economy. The study found negative influence of these aspects on FDI. Awan (2010) observed that foreign loans and investments fill gap between the savings investments; and exports and imports of a country. Moreover it was found that repayments of debts and GDP have not imparted the FDI in Pakistan. Khan et al. (2012) found that exchange rate and FDI have deep rooted mutual relationship having two way effects i.e. exchange rate affects FDI and FDI affects exchange rate. The two directional positively related linkage between FDI and exchange rate may be elaborated as a rise in exchange rate leads to value addition of foreign currency, it resultantly causes a decline in production costs in domestic host currency, which is an attraction for foreign investors. Khan (2007) stated that poor law and order situation in the country, indifferent and casual attitude of bureaucrats, under developed communication system, ever changing financial and industrial policies, corruption, inefficiency and bad governance on part of government owned departments and legal disputes between foreign investors and the government had a negative effect on FDI.

\section{Methodology}

On the basis of the review of literature it may be concluded that FDI inflows are dependent on various economic, political, legal and social factors. This study however focuses on economic factors in general and macroeconomic factors in particular. The study aimed to empirically analyze the impact of selected macroeconomic variables - GDP, Inflation and Real Exchange Rate on FDI inflows in Pakistan. Hence for the purpose of conducting this study FDI inflows are taken as dependent variable whereas GDP, Inflation and Real Exchange Rate are taken as explanatory or independent variables.

\section{Data Collection}

Secondary data is used to conduct the study to generalize the relationship between macroeconomic indicators and the FDI inflows in Pakistan. Time series data for four decades covering year 1971 to year 2009 have been taken to conduct the study. Data has been taken form World Development Indicator, State Bank of Pakistan, International Monetary Fund and Annual Economic Survey of Pakistan.

\section{Measurement of Variables}

On the basis of review of literature and the methodologies adopted earlier for such studies internationally, all the dependent and independent variables for the present study are measured through taking natural log of the actual data taken from the above mentioned secondary sources. The predicted relationship between the studied variable FDI and the explanatory variables GDP, Inflation and Real Exchange Rate can be mathematically expressed as: $\ln \mathrm{FDI}=\beta_{0}+\beta_{1} * \ln \mathrm{GDP}+\beta_{2} \ln \mathrm{INF}+\beta_{3} \ln$ EXRATE + Error Term

\section{Data Analysis}

The present study uses both descriptive and inferential statistics to analyze and evaluate the results. Descriptive Statistics have been used to know the structural properties of data. Inferential analysis covers correlation analysis, regression analysis, unit root analysis and co integration analysis. Pearson Correlation is used for correlation analysis to know the direction of relationship between variables. Ordinary Least Square method is used for regression analysis to measure the strength and significance of relationship (Gul, 2012). Augmented Dickey-Fuller (ADF 1979) test statistics and Phillip Peron unit root test is used to test the data stationarity (Ahmad et al, 2003; Shah et al, 2003; Afzal et al, 2004; Yousaf, 2008). Johansen Juselius Cointegration test (1990) is used for data co integration (Aqeel \& Nishat, 2005) to find out whether or not variables included are integrated at same order. E-views 7 software is used for data analysis.

\section{Descriptive Analysis}

\section{Discussion \& Analysis}

Table - 4.1

Descriptive Statistics

\begin{tabular}{|c|c|c|c|c|c|c|c|c|c|c|}
\hline$\frac{\frac{\mathscr{E}}{0}}{\sqrt{\frac{\pi}{3}}}$ & 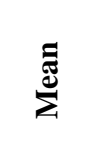 & 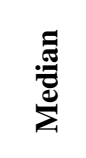 & 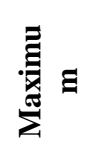 & 䓃 & $\stackrel{\theta}{\dot{s}}$ & $\frac{\mathscr{E}}{\mathscr{E}}$ & 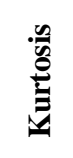 & 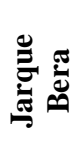 & $\frac{1}{0}$ & 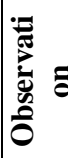 \\
\hline FDI & 19.03 & 19.31 & 22.44 & 13.81 & 1.94 & -0.44 & 3.12 & 1.29 & 0.52 & 39 \\
\hline GDP & 24.39 & 24.41 & 25.82 & 22.56 & 0.83 & -0.30 & 2.41 & 1.16 & 0.55 & 39 \\
\hline
\end{tabular}




\begin{tabular}{|c|c|c|c|c|c|c|c|c|c|c|}
\hline INF & -2.52 & -2.53 & -1.32 & -3.53 & 0.54 & 0.17 & 2.65 & 0.39 & 0.82 & 39 \\
\hline EXR & 3.16 & 3.08 & 4.43 & 1.56 & 0.78 & $\overline{-}-0.008$ & 1.73 & 2.61 & 0.26 & 39 \\
\hline
\end{tabular}

The above descriptive statistics (Table 4.1) show the descriptive properties of studied variables over the period 1970 to 2009. Jarque-Bera statistics test the goodness of fit of the sample data by checking the skewness and kurtosis of the data for normal distribution. If the data is normally distributed Jarque Bera statistic asymptotically has a chi squared distribution with two degrees of freedom. The null hypothesis is a joint hypothesis of the skewness and excess kurtosis to be zero. The reported probability of the Jarque Bera statistics above accepts the null hypothesis of normal distribution of observed data. The skewness statistics show that FDI, GDP and Exchange Rate are negatively skewed, which depicts the left tail to be longer and so the more of the data distribution is towards right of the figure. So it is concluded that these three variables have relatively fewer low values as per relative mean values. The skewness statistics for Inflation Rate show that data series is positively, which depicts the right tail to be longer and so the more of the data distribution is towards left of the figure. So it is concluded that these three variables have relatively more low values as per relative mean values. Mean values show that GDP has the highest rate of change among all variables whereas the inflation has the lowest rate of change. Standard deviation depicts that FDI values are more vulnerable to deviate as against the expected values whereas the inflation has the least potential to deviate from the expected figures.

\section{Inferential Analysis}

Table - 4.2

Correlation Matrix

\begin{tabular}{|c|l|l|l|l|}
\hline & FDI & GDP & INF & EXRATE \\
\hline FDI & 1.000 & 0.912 & 0.007 & 0.908 \\
\hline GDP & 0.912 & 1.000 & -0.183 & 0.930 \\
\hline INF & 0.007 & -0.183 & 1.000 & -0.158 \\
\hline EXRATE & 0.908 & 0.930 & -0.158 & 1.000 \\
\hline
\end{tabular}

The correlation matrix above (Table 4.2) shows that FDI is positively correlated to all three variables GDP, Exchange rate and Inflation. It indicates presence of integration in the market and it may be due to high inflow of capital in the economy. The lower level of correlation of inflation attracts more opportunities for the foreigners to invest in Pakistan.

Table - 4.3

Unit Root Test - Augmented Dickey Fuller

\begin{tabular}{|c|c|c|c|c|c|c|}
\hline & \multicolumn{3}{|c|}{$\begin{array}{c}\text { Augmented Dickey Fuller } \\
\text { (At level) }\end{array}$} & \multicolumn{3}{c|}{$\begin{array}{c}\text { Augmented Dickey Fuller } \\
\text { (First Difference) }\end{array}$} \\
\hline VARIABLES & Intercept & $\begin{array}{c}\text { Trend } \\
\text { Intercept }\end{array}$ & None & Intercept & $\begin{array}{c}\text { Trend } \\
\text { Intercept }\end{array}$ & None \\
\hline FDI & -1.283 & -4.281 & 1.316 & -9.043 & -8.959 & -8.338 \\
\hline GDP & -0.814 & -2.587 & 2.940 & -7.580 & -2.587 & 2.940 \\
\hline INF & -3.068 & -3.250 & -0.860 & -5.364 & -5.371 & -5.471 \\
\hline EXRATE & 0.959 & -2.810 & 4.881 & -4.298 & -4.382 & -2.684 \\
\hline
\end{tabular}

Table - 4.3

Unit Root Test - Phillip Peron

\begin{tabular}{|c|c|c|c|c|c|c|}
\hline & \multicolumn{3}{|c|}{$\begin{array}{c}\text { Phillip Peron } \\
\text { (At Level) }\end{array}$} & \multicolumn{3}{c|}{$\begin{array}{c}\text { Phillip Peron } \\
\text { (At First Difference) }\end{array}$} \\
\hline Variables & Intercept & $\begin{array}{c}\text { Trend } \\
\text { Intercept }\end{array}$ & None & Intercept & $\begin{array}{c}\text { Trend } \\
\text { Intercept }\end{array}$ & None \\
\hline FDI & -2.645 & -6.120 & 1.607 & -10.391 & -10.133 & -9.363 \\
\hline GDP & -0.184 & -2.315 & 3.735 & -5.349 & -5.224 & -4.016 \\
\hline INF & -3.013 & -3.071 & -0.894 & -6.179 & -6.077 & -6.262 \\
\hline EXRATE & -1.354 & -4.310 & 3.030 & -11.618 & -11.781 & -8.351 \\
\hline
\end{tabular}


Unit root test was conducted on the collected data to check the stationarity of data since the least square technique gives reliable results if the data is stationary. For this purpose two tests are applied namely Augmented Dickey Fuller (ADF) and Phillip Peron (PP) to test the data stationarity. The results of ADF showed that all variables are non stationary at level and at first difference, hence PP test was used. The results of PP test indicated that all variables become stationary at the first difference with intercept, trend \& intercept and none.

Table - 4.4

Johnson Co Integration Test

\begin{tabular}{|l|l|c|c|c|}
\hline \multicolumn{5}{|l|}{ Observation : 39 } \\
\hline \multicolumn{4}{|l|}{ Series : FDI,GDP,INF,EXRATE } \\
\hline Lags 1 to 1 \\
\hline $\begin{array}{c}\text { Eigen } \\
\text { Value }\end{array}$ & $\begin{array}{c}\text { Likelihood } \\
\text { Ratio }\end{array}$ & $\begin{array}{c}\mathbf{5 \%} \\
\text { Critical } \\
\text { Value }\end{array}$ & $\begin{array}{c}\mathbf{1 \%} \\
\text { Critical } \\
\text { Value }\end{array}$ & $\begin{array}{c}\text { Hypothesized } \\
\text { No. of CE(s) }\end{array}$ \\
\hline 0.536 & 72.742 & 46.19 & 53.35 & NONE** \\
\hline 0.479 & 44.285 & 28.86 & 36.55 & At most 1** \\
\hline 0.405 & 20.097 & 14.51 & 24.14 & At most 2** \\
\hline 0.0226 & 0.847 & 4.67 & 7.56 & At most 3 \\
\hline
\end{tabular}

** denotes Hypothesis rejected at $5 \%$ and $1 \%$ significance level

Log likelihood Ratio (L.R) satisfied three equations at 5\% significance level

Johnson Co Integration Test is used to test co integration among series of variables. The results show null hypothesis rejection at 5\% significance. Log likelihood Ratio also satisfied co integrating equation at 5\% significance level. The assumption which is used in this co integration test is intercept with no trend and vector auto regressive (VAR) with linear deterministic trend.

Table - 4.5

Least Square Estimation

\begin{tabular}{|c|c|c|c|c|}
\hline \multicolumn{5}{|c|}{ Dependant Variable : FDI } \\
\hline \multicolumn{5}{|c|}{ Sample : 139} \\
\hline \multicolumn{5}{|c|}{ Included observation : 39} \\
\hline Variables & Coefficient & Std. Error & T-statistic & Prob. \\
\hline GDP & 1.260 & 0.358 & 3.519 & 0.0012 \\
\hline INF & 0.624 & 0.205 & 3.041 & 0.0044 \\
\hline EXRATE & 1.066 & 0.383 & 2.780 & 0.0087 \\
\hline C & -13.524 & 7.588 & -1.782 & 0.0834 \\
\hline R-squared & 0.8879 & \multicolumn{2}{|c|}{ Mean dependant var } & 19.0386 \\
\hline Adjusted R-Squared & 0.8783 & \multicolumn{2}{|c|}{ S.D. dependant var } & 1.9417 \\
\hline S.E of Regression & 0.6772 & \multicolumn{2}{|c|}{ Akaike info criterion } & 2.1554 \\
\hline Sum squared resid & 16.0546 & \multicolumn{2}{|c|}{ Schwarz criterion } & 2.3260 \\
\hline Log Likelihood & -38.0310 & \multicolumn{2}{|l|}{ F-Statistic } & 92.4522 \\
\hline Durbin Watson stat & 1.8665 & \multicolumn{2}{|c|}{ Prob(F-Statistics) } & 0.0000 \\
\hline
\end{tabular}

Ordinary Least Square technique is used for time series data to test the strength and significance of the explanatory variables against the dependent variable. The results significantly disclosed that the value of coefficient of GDP, inflation \& exchange rate are positive \& significant at $1 \%$ level, hence it can be concluded that all the three explanatory variables are positively associated to the dependent variable FDI. So any increase in the three explanatory variables would cause an increase in FDI, therefore government should focus on stabilizing these variables to attract more FDI in to the country to support the economic growth of the country. The coefficient values explain the beta coefficients of the explanatory variables and their effect on the dependent variables. The resultant equation can be expressed mathematically as:

$$
\mathrm{FDI}=-13.52+1.26 \mathrm{GDP}+0.62 \mathrm{INF}+1.06 \mathrm{EXRATE}+0.67
$$

Probability of F-statistics also shows that model is overall significant at $1 \%$ level. The value of $\mathrm{R}^{2}$ denotes that about $89 \%$ of the variations in dependent variable are explained by the variations in the explanatory variables.

\section{Conclusion \& Recommendations}

The study attempted to examine the impact of macroeconomic variable on FDI in Pakistan. The study evaluated annual time series data covering 1971 to 2009 related to core economic indicators. Various other economic variables along with other non economic variables like political, legal and social factors could also affect the FDI inflows in Pakistan. This study is restricted to identify the impact of only three selected core 
economic indicators that have been mostly found in the earlier literature. The findings suggested that macroeconomic variables like GDP, inflation, exchange rate have significant positive impact on FDI inflows in Pakistan. Hence to improve the rate of FDI inflow in the country for augmenting the overall economic growth, the government must pay more emphasis to the stability and monitoring of the explanatory variables cautiously. GDP of Pakistan has significant effect on FDI therefore there should be more effort to maintain and increase the growth rate of GDP consistently. It will help the government in order to attract foreign investors in Pakistan for the growth of economy as a result. Moreover government should also monitor and control the rate of inflation, as it also affects the overall FDI inflows in the country. Similarly there is a need of stable exchange rate in Pakistan which may augment FDI inflow in Pakistan. There is a need of consistent financial policies followed by the succeeding governments, to encourage and enhance the confidence of foreign investors. Likewise trade policy should be framed out to create a lucrative environment for the prospective investors. Moreover proper provision of communication networks, logistics support, energy supply, law and order prevalence and security assurance should be ensured to attract foreign investors.

\section{References}

[1] Anwar, S. \& Ngu, L. P. (2010), Foreign direct investment and economic growth in Vietnam, Asia Pacific Business Review, Vol. 16, Nos. 1-2, 183-202

[2] Aqeel, A. \& Nishat M. (2004), The determinants of foreign direct investment in Pakistan, The Pakistan Development Review, 43(4) II, 651-664.

[3] Aqeel, A. \& Nishat, M. (2005), The determinants of foreign direct investment in Pakistan, http://www.pide.org.pk/psde/papers_20AGM.html.

[4] Asheghian (2004)., Determinants of economic growth in the United States: the role of foreign direct investment, The International Trade Journal, Volume 18, Number 1, pp. 63-83(21)

[5] Asiedu, E. (2005), Foreign direct investment in Africa: the role of natural resources, market size, government policy, institutions and political instability, HTTP://SSRN.COM/ABSTRACT=717361 OR http://dx.doi.org/10.2139/ssrn.717361

[6] Attari, M. I. J., Kamal, Y. \& Attaria, S. N. (2011), The causal link between foreign direct investment and economic growth in Pakistan economy, The Journal of Commerce, Vol. 3, No. 4, ISSN: 2220-6043, 61-68.

[7] Aurangzeb; H. A. (2012), Factors affecting the trade balance in Pakistan, Economics and Finance Review, Vol. 1(11), pp. 25 - 30

[8] Awan, M. Z., Khan, B. \& Zaman, K. (2010), A nexus between foreign direct investment and Pakistan's eEconomy (co-integration \& error correction approach) International Research Journal of Finance and Economics, ISSN 1450-2887 Issue 52.

[9] Azam, K. M. \& Khattak, N. R. (2009), Effect of economic factors on foreign direct investment inflow: evidence from Pakistan (1971-2005), Sarhad Journal Agric, 25(1), 135-140.

[10] Aziz, M. S. (2009), Impact of global financial crisis on Pakistan, http://comment.fco.gov.uk/roller2/aziz/entry/impact_of_global_financial_crisis

[11] Falki, N. (2009), Impact of foreign direct investment on economic growth in Pakistan, International Review of Business Research Papers, Vol. 5(5), pp. 110-120

[12] Gul, S., Sajid, M., Afzal, F., Khan, M. B. \& Mughal, S. (2012), Factors influencing foreign direct investment - The case of Pakistan, Economics and Finance Review, vol. 2(2), pp. 21-25, http://ideas.repec.org/p/pid/wpaper/201167.html

[13] Hussain, S. A. (2012), Analysis of three economies, same challenges, The News, Money Matters pg.II.

[14] Khan, M. A. (2007), Foreign direct investment and economic growth: the role of domestic financial sector, PIDE working Papers 18, Pakistan Development Review, http://ideas.repec.org/p/pid/wpaper/200718.html

[15] Khan, R. E. A., Sattar, R. \& Rehman, H (2012), Effectiveness of exchange rate in pakistan: causality analysis, Pakistan Journal of Commerce and Social Sciences Vol. 6 (1), 83-96

[16] Khan, S. A. \& Khan, M. A. (2011), Foreign direct investment and economic growth in Pakistan, A sectoral analysis, PIDE Working Papers 2011, 67, pp.1-22

[17] Kok, R., \& Ersoy, A. B. (2009), Analyses of FDI determinants in developing countries, International Journal of Social Economics, $36(1 / 2), 105-123$

[18] Levis, (1979), Does political instability in developing countries affect foreign investment flow, Management International Review, JSTOR, vol 19, no 3, pp 59-68

[19] Mahmood, I., Ehsanullah \& Ahmed, H. (2011), Exchange rate volatility \& macroeconomic variables in Pakistan, Business Management Dynamics, Vol.1, No.2, August 2011, pp.11-22

[20] Mahmood, I. \& Ehsanullah (2011), Macroeconomic variables and FDI in Pakistan, European Journal of Scientific Research, ISSN 1450-216, Vol.55, No.3 (2011), pp.388-393

[21] Sahoor (2006), Foreign direct investment in South Asia: policy, trend, impact and determinants, Asian Development Bank Institute, Discussion Paper No.56, www.adbi.org/files/dp56_fdi_in_south_asia.pdf

[22] Santiago, C.E. (1987), The impact of foreign direct investment on export structure and employment generation, World Development Report, 15 (3), 317-328

[23] Shah, Z. \& Ahmed, Q. M. (2004), The determinants of foreign direct investment in Pakistan: an empirical investigation, The Pakistan Development Review, 42:4, Part 2, Winter 2003, pp 697-714

[24] Sultana, S. \& Syed, A. A. (2010), Macro economics determinants of savings and investment in Pakistan, Journal of Business Strategies, Vol.4, Issue 2, ISSN 1993-5765, pg. 5.

[25] Yousaf, M. M., Hussain, Z. \& Ahmad, N. (2008), Economic evaluation of foreign direct investment in Pakistan, Pakistan Economic and Social Review, Volume 46, pp. 37-56

[26] Yousaf, U., Nasir, A., Naqvi, F. N., Haider, A. \& Bhutta, N. A. (2011), Impact of foreign direct investment on economic growth of Pakistan, European Journal of Economics, Finance and Administrative Sciences, ISSN 1450-2275, Issue 32, pg. 95-100

[27] Zaman, K; Shah, I. A., Khan, M. M. \& Ahmad, M. (2012), Macroeconomic factors determining FDI impact on Pakistan's growth, South Asian Journal of Global Business Research, Vol. 1, Issue 1, pp.79- 95 